\title{
Enhanced rainfall in the Western Mediterranean during deposition of sapropel S1: stalagmite evidence from Corchia cave (Central Italy)
}

\author{
G. Zanchetta ${ }^{\mathrm{a}, *}$, R.N. Drysdale ${ }^{\mathrm{b}}$, J.C. Hellstrom ${ }^{\mathrm{c}}$, A.E. Fallick ${ }^{\mathrm{d}}$, I. Isola ${ }^{\mathrm{e}}$, \\ M.K. Gagan ${ }^{\text {f }}$ M.T. Pareschi ${ }^{\mathrm{e}}$ \\ ${ }^{a}$ Dipartimento di Scienze della Terra, University of Pisa, Via S. Maria 53, 56126 Pisa, Italy \\ ${ }^{\mathrm{b}}$ School of Environmental and Life Sciences, University of Newcastle, Callaghan, NSW 2308, Australia \\ ${ }^{\mathrm{c}}$ School of Earth Sciences, University of Melbourne, Parkville, Victoria 3010, Australia \\ ${ }^{\mathrm{d}}$ Scottish Universities Environmental Research Centre, East Kilbride, G75 OGF Glasgow, UK \\ ${ }^{\mathrm{e}}$ Instituto Nazionale di Geofisica e Vulcanologia, Sezione di Pisa, Via della Faggiola 32, 56126 Pisa, Italy \\ ${ }^{\mathrm{f}}$ Research School of Earth Sciences, The Australian National University, Canberra ACT 0200, Australia
}

Received 5 May 2006; received in revised form 22 November 2006; accepted 5 December 2006

\begin{abstract}
A stable isotope record from a stalagmite collected from Antro del Corchia cave (Apuan Alps, Central Italy), supported by 17 uranium-series ages, indicates enhanced regional rainfall between ca 8.9 and $7.3 \mathrm{kyr}$ cal. BP at the time of sapropel S1 deposition. Within this phase, the highest rainfall occurred between 7.9 and $7.4 \mathrm{kyr}$ cal. BP. Comparison with different marine and lake records, and in particular with the Soreq Cave record (Israel), suggests substantial in-phase occurrence of enhanced rainfall between the Western and Eastern Mediterranean basins. There is no convincing evidence for major climatic change at the time of the " $8.2 \mathrm{kyr}$ event".
\end{abstract}

(C) 2006 Elsevier Ltd. All rights reserved.

\section{Introduction}

In contrast to the last glacial period, climate proxy records show that the Holocene has been characterised by only minor temperature fluctuations (Alley et al., 1997). However, significant oceanographic and hydrologic changes have occurred, particularly in the middle and low latitudes (Mayewski et al., 2004). A notable example is the climate associated with sapropel S1, which was deposited in the eastern and central Mediterranean basins during the Early-Mid Holocene (ca 6600-9500 yr cal. BP: e.g. Emeis et al., 2000). Sapropels are organic-carbon-rich layers usually found intercalated with the more typical organic-poor carbonate sediments of the Mediterranean. Several hypotheses exist on the origin of sapropels (e.g. Rohling, 1994; Emeis et al., 2000). Many of these invoke an increase in terrestrial runoff, most likely from the Nile basin (Krom et al., 2002; Sperling et al., 2003). This runoff appears to have reduced surface-water salinity, with

\footnotetext{
${ }^{*}$ Corresponding author. Tel.: + 390502215795 ; fax: + 390502215800 .

E-mail address: zanchetta@dst.unipi.it (G. Zanchetta).
}

consequent deep-water stratification and anoxia (Emeis et al., 2000). Sapropels are climatically significant because they are thought to be linked to episodes of enhanced monsoon activity corresponding to minima in Earth's orbital precession (Rossignol-Strick et al., 1982; Emeis et al., 2000).

Most of the lithostratigraphic evidence for S1 is found in marine cores of the Adriatic Sea, and the Ionian and Levantine Basins (Emeis et al., 2000; Giunta et al., 2003; Fig. 1). However, its distribution through these basins is discontinuous (Ariztegui et al., 2000), and its timing is difficult to constrain due to varying degrees of preservation, problems with calibrating marine radiocarbon ages and the spatial complexity of the circulation and biogeochemical changes which took place (e.g. Thomson et al., 1999; Siani et al., 2001). In spite of its tropical origin, there is increasing evidence that the zone which experienced increased rainfall at this time included the Mediterranean region itself (Kallel et al., 1997, 2000; Rossignol-Strick, 1999; Bar-Matthews et al., 2000, 2003; Magny et al., 2002). In order to better define the climatic conditions throughout the Mediterranean region and to assist in land-sea 

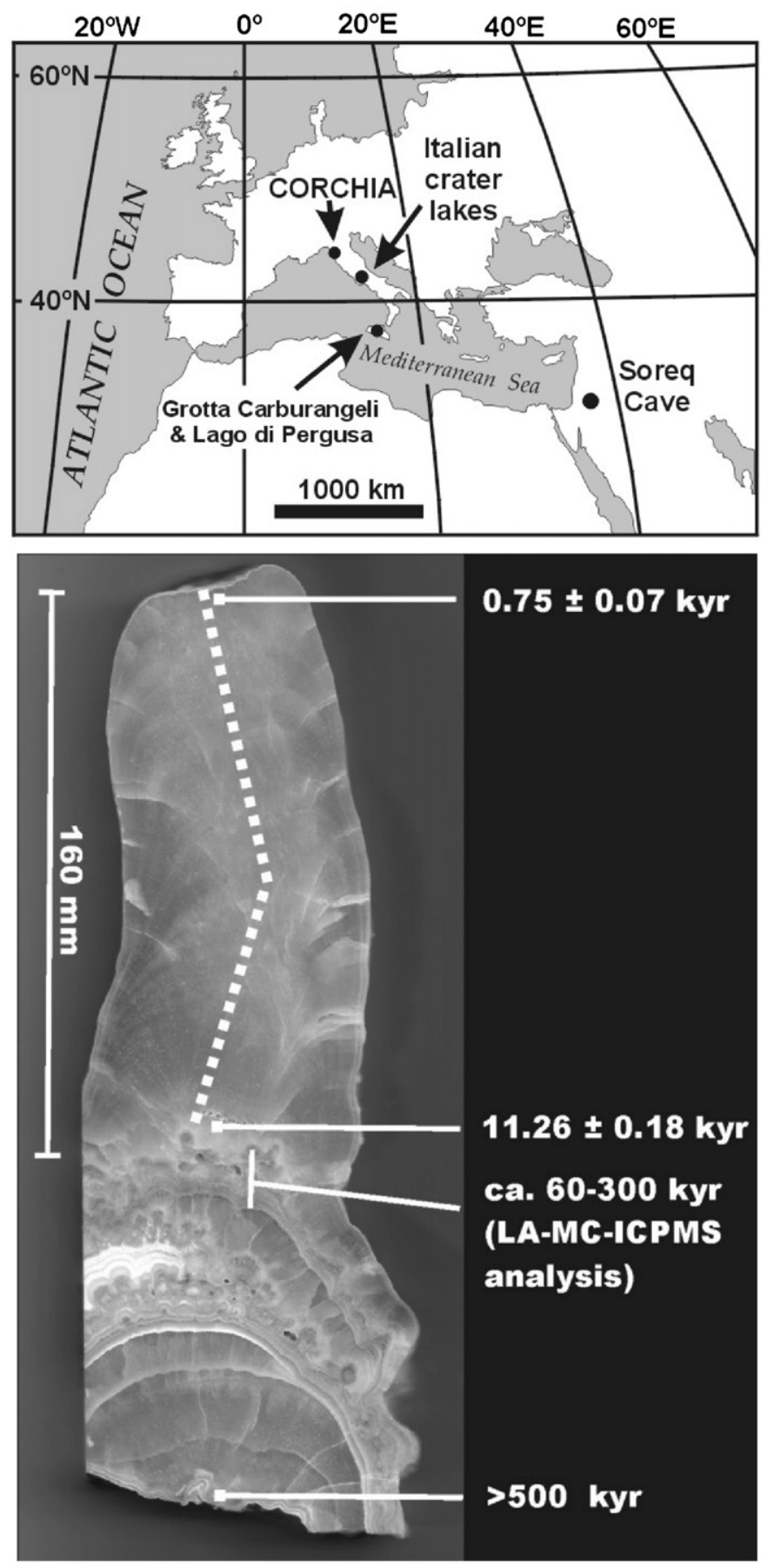

Fig. 1. Upper: the Mediterranean basin showing the location of Antro del Corchia and the main study sites discussed in the text. Lower: polished section of CC26 stalagmite. Note the popcorn-shaped layers in the lower part of the section indicating slow growth and hiatus. The dashed line indicates the growth axes sampled for stable isotopes analyses. The locations of reconnaissance U-Th analyses (LA-MC-ICPMS: laser ablation multi-collector inductively coupled plasma mass spectrometry) are also shown as reference points.

correlations of this event, continuous and well-dated terrestrial records are needed from archives sensitive to millennial-scale changes in regional hydrology.

Speleothems are cave calcium carbonate deposits with a demonstrated capacity for preserving climate changes during Mediterranean sapropel events (Bar-Matthews et al., 2000, 2003; Bard et al., 2002). In this paper, we present a precisely dated isotopic record from a speleothem collected from Antro del Corchia, Central Italy, which displays direct evidence of increased rainfall in the region during the period of $\mathrm{S} 1$ deposition and provides an opportunity for correlation with nearby marine- and lake-core records.

\section{Methods}

Our data are derived from a ca $25 \mathrm{~cm}$-tall inactive stalagmite (CC26) collected in situ from a deep chamber within Antro del Corchia $\left(43^{\circ} 59^{\prime} \mathrm{N}, 10^{\circ} 13^{\prime} \mathrm{E}\right.$; Fig. 1$)$, a cave formed in steeply dipping Mesozoic marbles and dolostones of the Alpi Apuane. The sampling site (Galleria delle Stalattiti, $\sim 840 \mathrm{~m}$ a.s.l.) is situated ca $400 \mathrm{~m}$ below the surface and ca $500 \mathrm{~m}$ from the nearest entrance to the cave. The chamber has a constant mean annual temperature of $7.5^{\circ} \mathrm{C}$ and receives recharge of $2500-3000 \mathrm{~mm} / \mathrm{yr}$ over an elevation range of ca 1200-1400 m (Drysdale et al., 2004). The surface above the cave is very steep and rugged, and contains large areas of bare karst rock. The sparse vegetation cover is confined to pockets of soil-filled solution features. The regional climate has a predominantly North Atlantic influence and recharge to the cave is derived principally from frontal systems arriving from the west (Drysdale et al., 2004).

Drip-waters in the chamber have a near-constant oxygen isotopic composition $\left(\delta^{18} \mathrm{O}\right.$ : ca $-7.4 \%$ ) which is consistent with predicted values of rainfall at the estimated recharge elevation (Drysdale et al., 2004). The carbon isotope composition $\left(\delta^{13} \mathrm{C}\right)$ of dissolved inorganic carbon (DIC) is similarly constant (ca -4\%o) and reflects the low contribution from biogenic $\mathrm{CO}_{2}$ due to the thin vegetation cover and cool mean annual temperatures. Spring water samples collected at lower altitudes and fed by more vegetated recharge areas show consistently lower (as low as $-17 \%$ ) $\delta^{13} \mathrm{C}$ values of DIC (Doveri et al., 2005). Preliminary data on the tritium content of the drip waters in the Galleria delle Stalattiti suggest that the waters have a mean residence time in the aquifer of ca $50 \mathrm{yr}$ (Doveri et al., 2005).

As with most stalagmites collected from Antro del Corchia, CC26 comprises almost exclusively translucent to opaque, elongate columnar calcite (Frisia et al., 2000) with massive to faintly laminated fabrics and no visible signs of diagenesis. After sectioning, the internal stratigraphy of CC26 revealed several phases of deposition (Fig. 1). The results of radiometric ${ }^{230} \mathrm{Th}-{ }^{234} \mathrm{U}$ dating and the lack of visible hiatuses suggest that the upper ca $160 \mathrm{~mm}$ section grew continuously from the Lateglacial to the Little Ice Age (Table 1). The upper section was sampled at $200 \mu \mathrm{m}$ increments using a micro-milling method developed at the Research School of Earth Sciences, The Australian National University (Gagan et al., 1994). The stable isotope composition of the powders was measured on 
Table 1

U-Th isotopic data and corrected ages for stalagmite CC26, determined by following the procedure of Hellstrom (2003)

\begin{tabular}{|c|c|c|c|c|c|c|c|c|}
\hline Sample & Depth (mm) & $U(\mathrm{ppb})$ & {$\left[{ }^{230} \mathrm{Th} /{ }^{238} \mathrm{U}\right]$} & {$\left[{ }^{234} \mathrm{U} /{ }^{238} \mathrm{U}\right]$} & {$\left[{ }^{232} \mathrm{Th} /{ }^{238} \mathrm{U}\right] \times 10^{3}$} & Age (kyr) & {$\left[{ }^{234} \mathrm{U} /{ }^{238} \mathrm{U}\right]_{\text {init }}$} & {$\left[{ }^{230} \mathrm{Th} /{ }^{232} \mathrm{Th}\right]$} \\
\hline CC26-4 & $4.1(0.3)$ & 6481 & 0.0046 (4) & 0.6639 (13) & 0.1068 (15) & $0.75(7)$ & 0.6632 (13) & 43.4 \\
\hline CC26-5 & $27.0(0.3)$ & 4256 & $0.0151(4)$ & $0.6643(13)$ & $0.1982(15)$ & $2.48(7)$ & $0.6619(13)$ & 76.2 \\
\hline $\mathrm{CC} 26-3$ & $45.4(0.3)$ & 4217 & 0.0235 (4) & $0.6652(14)$ & $0.1719(70)$ & $3.90(7)$ & $0.6615(14)$ & 136.8 \\
\hline CC26-6 & $54.3(0.3)$ & 4657 & $0.0278(4)$ & $0.6647(18)$ & $0.1116(20)$ & $4.65(7)$ & $0.6602(18)$ & 249.5 \\
\hline CC26-7 & $68.2(0.3)$ & 4976 & 0.0333 (4) & $0.6690(15)$ & $0.0531(7)$ & $5.57(7)$ & $0.6638(15)$ & 627.8 \\
\hline CC26-2 & $77.4(0.3)$ & 5240 & 0.0359 (4) & $0.6714(13)$ & $0.0502(25)$ & $6.00(6)$ & 0.6658 (13) & 715.7 \\
\hline $\mathrm{CC} 26-8$ & $84.6(0.3)$ & 4710 & $0.0390(6)$ & $0.6719(16)$ & $0.0357(6)$ & $6.54(11)$ & $0.6657(17)$ & 1092.4 \\
\hline CC26-9 & $86.2(0.3)$ & 5781 & $0.0391(7)$ & $0.6745(15)$ & $0.0246(11)$ & $6.52(12)$ & $0.6685(15)$ & 1586.1 \\
\hline CC26-10 & $95.9(0.3)$ & 4734 & $0.0430(8)$ & $0.6767(19)$ & $0.0305(18)$ & $7.16(13)$ & $0.6700(19)$ & 1408.5 \\
\hline CC26-11 & $102.3(0.3)$ & 4560 & $0.0452(7)$ & $0.6718(15)$ & $0.0136(6)$ & $7.62(12)$ & $0.6647(16)$ & 3329.7 \\
\hline CC26-12 & $108.0(0.3)$ & 5513 & $0.0475(9)$ & $0.6744(14)$ & $0.0419(28)$ & $7.98(16)$ & $0.6669(15)$ & 1134.5 \\
\hline CC26-13 & $112.1(0.3)$ & 5478 & $0.0487(10)$ & $0.6737(18)$ & $0.0245(14)$ & $8.20(18)$ & $0.6660(18)$ & 1982.6 \\
\hline CC26-14 & $123.1(0.3)$ & 4796 & $0.0522(8)$ & $0.6755(14)$ & $0.0166(17)$ & $8.80(14)$ & $0.6673(15)$ & 3148.6 \\
\hline CC26-15 & $133.3(0.3)$ & 4745 & $0.0565(10)$ & $0.6775(18)$ & 0.0125 (13) & $9.54(18)$ & $0.6686(19)$ & 4530.4 \\
\hline CC26-16 & $141.7(0.3)$ & 5292 & 0.0597 (10) & $0.6750(20)$ & $0.0292(15)$ & 10.14 (18) & $0.6655(21)$ & 2043.4 \\
\hline CC26-1 & $150.7(2.0)$ & 4265 & 0.0639 (9) & $0.6729(20)$ & $0.0224(17)$ & $10.93(17)$ & $0.6626(21)$ & 2848.0 \\
\hline CC26-17 & $151.6(0.3)$ & 6461 & $0.0659(10)$ & $0.6744(17)$ & $0.0199(11)$ & $11.26(18)$ & 0.6639 (18) & 3316.2 \\
\hline
\end{tabular}

The activity ratios $\left[{ }^{230} \mathrm{Th} /{ }^{238} \mathrm{U}\right]$ and $\left[{ }^{234} \mathrm{U} /{ }^{238} \mathrm{U}\right]$ have been standardized to the HU-1 secular equilibrium standard. Ages were calculated using decay constants of $9.195 \times 10^{-6} \mathrm{yr}^{-1}\left({ }^{230} \mathrm{Th}\right)$ and $2.835 \times 10^{-6} \mathrm{yr}^{-1}\left({ }^{234} \mathrm{U}\right)$, and an assumed initial $\left[{ }^{230} \mathrm{Th} /{ }^{232} \mathrm{Th}\right]$ of $0.8 \pm 0.7$. Depths are from the stalagmite tip, and numbers in brackets are the $95 \%$ uncertainties in the last digits given.

$\mathrm{CO}_{2}$ gas released by reaction with $105 \% \mathrm{H}_{3} \mathrm{PO}_{4}$ at $70{ }^{\circ} \mathrm{C}$, which was measured using an AP2003 mass spectrometer at SUERC (East Kilbride, UK). Isotopic results are reported using the conventional $\delta$ notation in per mille (\%), with reference to the Vienna Pee Dee Belemnite (V-PDB) standard; the $\delta^{18} \mathrm{O}$ of waters cited in the text are quoted with reference to Vienna Standard Mean Ocean Water (V-SMOW). Mean analytical reproducibility $( \pm 1 \sigma)$ was $\pm 0.06 \%$ and $\pm 0.07 \%$ for carbon and oxygen, respectively.

For U-Th dating, homogenized samples of up to $50 \mathrm{mg}$ were extracted using $0.7 \mathrm{~mm}(n=15)$ and $1 \mathrm{~mm}$ drill bits $(n=2)$. Sub-samples of ca $3 \mathrm{mg}$ were dissolved and spiked with a mixed ${ }^{229} \mathrm{Th} /{ }^{233} \mathrm{U}$ tracer before removal of the carbonate matrix using Eichrom TRU-Spec ion-exchange resin. The purified uranium and thorium fraction was introduced in dilute nitric acid to a $\mathrm{Nu}$ Instruments MCICP-MS, where ${ }^{230} \mathrm{Th} /{ }^{238} \mathrm{U}$ and ${ }^{234} \mathrm{U} /{ }^{238} \mathrm{U}$ activity ratios were measured simultaneously using a parallel ion-counting procedure that allows for full internal standardization of ion-counter gain, elemental fractionation and mass bias. Full details of the analytical technique are provided in Hellstrom (2003) and updated in the supplementary materials of Drysdale et al. (2005). Ages were calculated corrected for unsupported initial ${ }^{230} \mathrm{Th}$ on the basis of their measured ${ }^{232} \mathrm{Th} /{ }^{238} \mathrm{U}$ ratios and an assumed initial ${ }^{230} \mathrm{Th} /{ }^{232} \mathrm{Th}$ activity ratio of $0.8 \pm 0.7$, and the uncertainties on all ratios were fully propagated (Table 1). Because of their extremely low measured ${ }^{232} \mathrm{Th} /{ }^{238} \mathrm{U}$ ratios, the age effect of the ${ }^{230} \mathrm{Th}$ correction was less than $0.1 \%$ for the majority of samples.

The $\delta^{13} \mathrm{C}$ and $\delta^{18} \mathrm{O}$ time series were tied to a Monte Carlo-derived age-depth model as previously described by

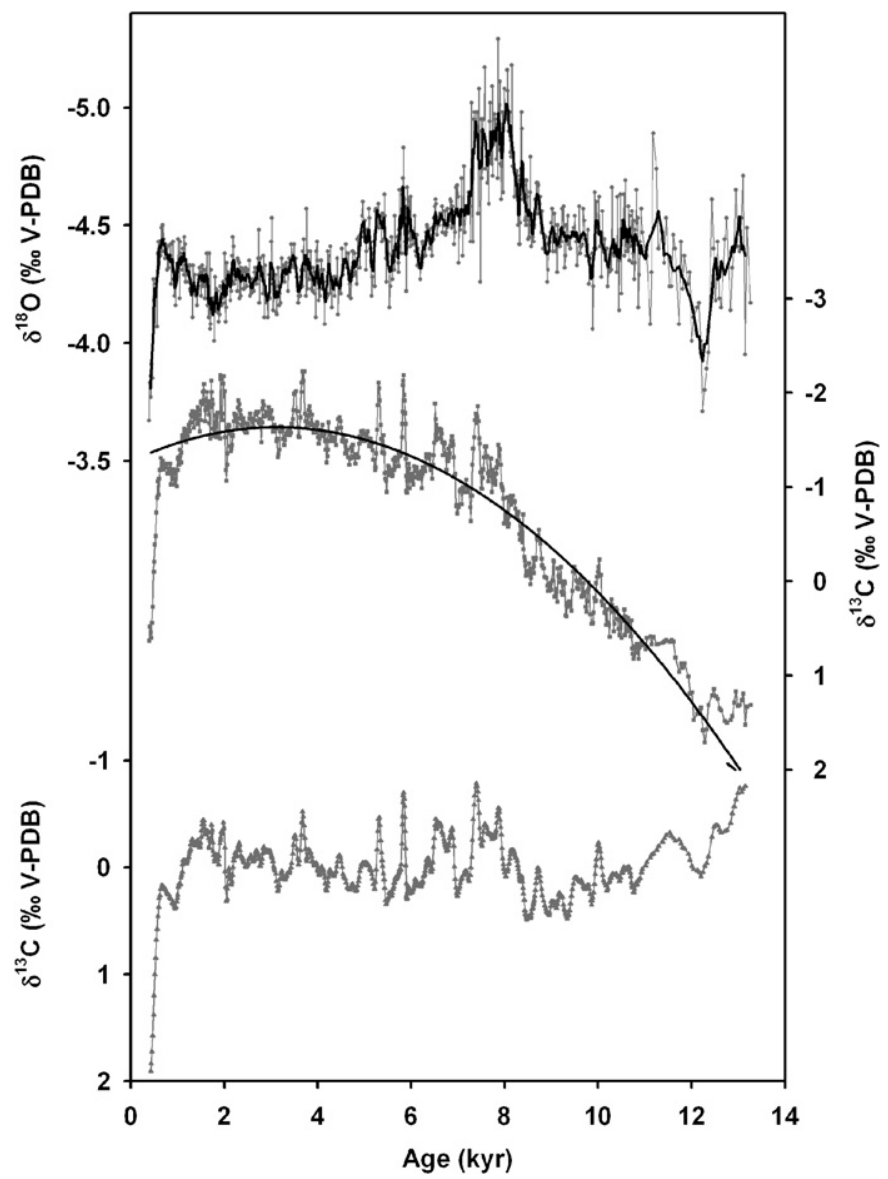

Fig. 2. The complete $\delta^{18} \mathrm{O}$ and $\delta^{13} \mathrm{C}$ time series of $\mathrm{CC} 26$ for the upper $160 \mathrm{~mm}$ (top two panels). The lower panel contains the detrended $\delta^{13} \mathrm{C}$ time series, where the second order polynomial fit (black line) was subtracted from the raw $\delta^{13} \mathrm{C}$ data. N.B.: The $y$-axes scale for $\delta^{18} \mathrm{O}$ and $\delta^{13} \mathrm{C}$ have been inverted. 
Drysdale et al. (2005) (Fig. 2). This model includes an uncertainty component that encompasses both spatial uncertainty introduced during the process of extracting powders for analysis, and temporal uncertainty arising from the corrected $\mathrm{U}-\mathrm{Th}$ age determinations.

\section{Results and interpretation}

All dated powders were of high purity $\left(\left[{ }^{230} \mathrm{Th} /{ }^{232} \mathrm{Th}\right]_{\text {activity: }}\right.$ : mean $=1663 ;$ Table 1) and produced ages in correct stratigraphic sequence (Table 1). The complete isotope time series is shown in Fig. 2. Here we focus on the interval from 5 to $10 \mathrm{kyr}$, which brackets the period of S1 deposition (Fig. 3). The most prominent feature of this interval in the CC26 record is the reduction in $\delta^{18} \mathrm{O}$ that commences stepwise at ca $8.9 \mathrm{kyr}$ and terminates abruptly at $7.3 \mathrm{kyr}$ (Figs. 2 and 3). Three possible mechanisms may explain this interval of low $\delta^{18} \mathrm{O}$ values. The first concerns changes in regional air temperatures, which can alter temperatures inside the cave (Gascoyne, 1992). Cave air temperature controls the degree of isotopic fractionation between cave drip waters and the calcite deposited from them. If drip water $\delta^{18} \mathrm{O}$ remains constant, an increase in cave temperature will cause a reduction in calcite $\delta^{18} \mathrm{O}$ at a rate of ca $-0.24 \% /{ }^{\circ} \mathrm{C}$ (at temperatures between 5 and $10^{\circ} \mathrm{C}$ : Kim and O’Neil, 1997).

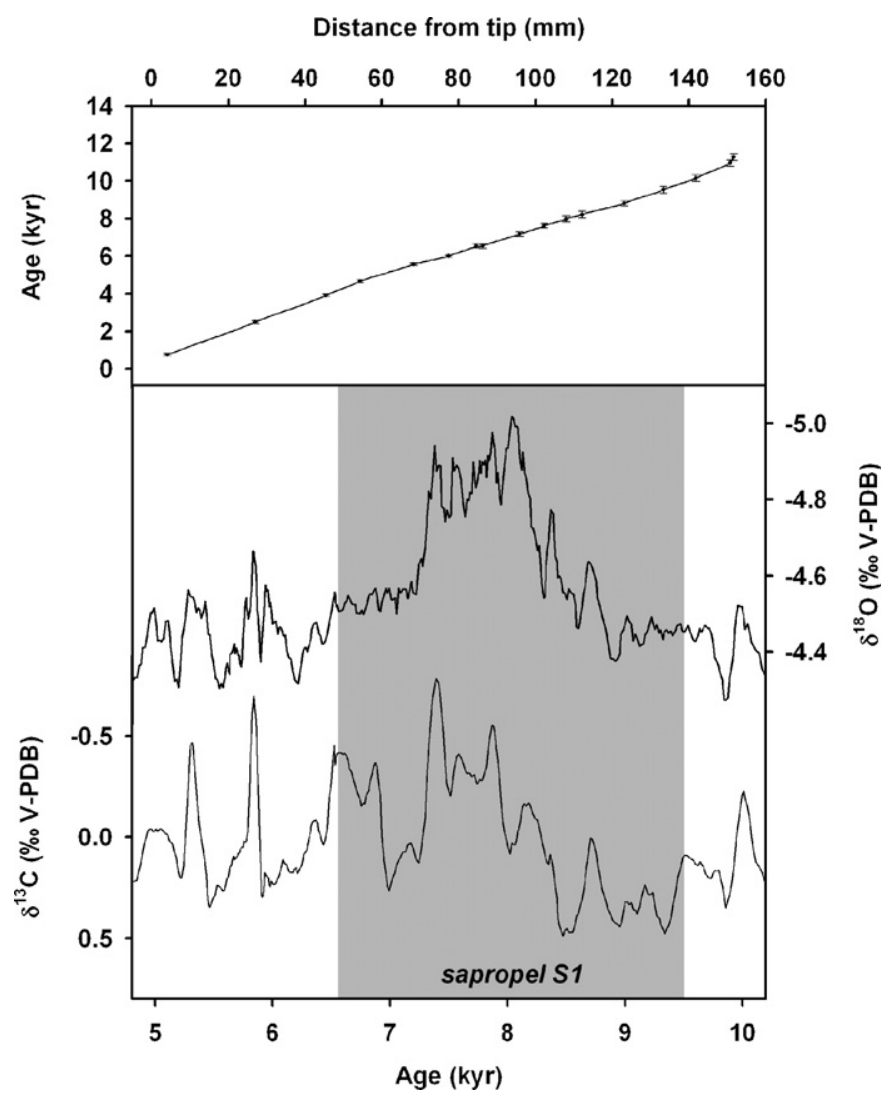

Fig. 3. Upper: depth-age model of $\mathrm{CC} 26$. Lower: $\delta^{18} \mathrm{O}$ and $\delta^{13} \mathrm{C}$ time series for the $5-10 \mathrm{kyr}$ period. The shadowed area represents the time of Sapropel S1 deposition according to Emeis et al. (2000). Note that the age of sapropel deposition varies according to different authors. N.B.: The $y$ axes scale for $\delta^{18} \mathrm{O}$ and $\delta^{13} \mathrm{C}$ have been inverted.
However, previous speleothem work from western Italy has shown that cave-temperature effects are likely to be counterbalanced by the influence of changing regional air temperatures on rainfall $\delta^{18} \mathrm{O}$, which is estimated to be $0.2-0.3 \%$ o $/{ }^{\circ} \mathrm{C}$ (Bard et al., 2002). Hence, if a temperature increase alone occurred, it would likely have had a negligible effect on speleothem $\delta^{18} \mathrm{O}$ at this site.

A second possible mechanism is the "rainfall amount" effect (Dansgaard, 1964), where rainfall $\delta^{18} \mathrm{O}$ decreases as rainfall amount increases. This is regarded as a principal mechanism driving variations in rainfall $\delta^{18} \mathrm{O}$ (and therefore drip-water and speleothem $\delta^{18} \mathrm{O}$ values) in the Mediterranean region (Bar-Matthews et al., 2000; Bard et al., 2002). In previously studied Corchia stalagmites, intervals of low $\delta^{18} \mathrm{O}$ correspond to wetter and warmer climatic periods (Drysdale et al., 2004, 2005, 2006), suggesting that the amount effect is coupled to regional temperatures. Such a coupling presumably arises due to greater evaporation from warmer versus cooler sea surfaces in the moisture source regions (i.e. the North Atlantic and Western Mediterranean).

A third possibility is a change in the composition and source of water vapour reaching the site. Studies of Western Mediterranean marine cores show evidence of reduced sea-surface $\delta^{18} \mathrm{O}$ during the time of $\mathrm{S} 1$ formation (e.g. Kallel et al., 1997, 2000; Emeis et al., 2000). For example, compared to the beginning of the Holocene, evidence from the Alboran and Southern Tyrrhenian Seas suggests a salinity decrease of ca 3\%o during S1 deposition (Kallel et al., 1997, 2000; Emeis et al., 2000). This decrease was partially recovered at the end of sapropel deposition. Today, the $\delta^{18} \mathrm{O} /$ salinity ratio for the Mediterranean Sea is ca 0.26 (Pierre, 1999). Although this ratio may have been higher during S1 deposition (e.g. Emeis et al., 2000), a firstorder estimate of the reduction in sea-surface $\delta^{18} \mathrm{O}$ during $\mathrm{S} 1$ based on the above ratio is ca $0.8 \%$. This may have been partly attributable to increased runoff to the marine environment from higher rainfall over continental areas bordering the Mediterranean (e.g. Kallel et al., 1997). The Western Mediterranean supplies about $40 \%$ of the moisture reaching central-western Italy, and modelling suggests this phenomenon persisted through glacial, stadial and interglacial climates (Bard et al., 2002). Hence, a more ${ }^{18} \mathrm{O}$-depleted sea surface would cause a reduction in vapour $\delta^{18} \mathrm{O}$, leading to a depletion in the isotopic composition of the recharge waters reaching the cave.

However, a substantial increase in runoff over the western Mediterranean basin would probably have been associated with a general reorganization of regional atmospheric circulation. For instance, in the Western Mediterranean an increase of rainfall amount is associated today with negative phases of the North Atlantic Oscillation, which induces a substantial increase in winter storms originating from the North Atlantic (Bolle, 2003; Hurrell et al., 2003). Meteoric precipitation from the North Atlantic has a lower $\delta^{18} \mathrm{O}$ compared to that of Western Mediterranean origin (Celle-Jeanton et al., 2001, 2004). 
Therefore, an increase in North Atlantic-sourced rainfall (the most important source of moisture for the Corchia Cave) could have magnified the effect on vapour masses of a more ${ }^{18} \mathrm{O}$-depleted sea surface.

Although there is marine-core evidence for a change in composition of at least one source of moisture, additional support for the rainfall amount effect must be sought from other properties of $\mathrm{CC} 26$. One potential source of supporting data is the $\delta^{13} \mathrm{C}$ time series. The full Holocene $\delta^{13} \mathrm{C}$ time series for $\mathrm{CC} 26$ displays the typical interglacial pattern found in older Corchia speleothems, where isotopic values steadily decrease as an interglacial progresses (Fig. 2; Drysdale et al., 2006), probably due to the time lag required for post-glacial soils to establish above the cave (Drysdale et al., 2004). The range of $\delta^{13} \mathrm{C}$ values in $\mathrm{CC} 26$ is comparable with those predicted from the $\delta^{13} \mathrm{C}$ of the DIC in modern cave drip waters (mean DIC $\delta^{13} \mathrm{C}$ values: $-4.1 \pm 0.6 \%$; Doveri et al., 2005). However, the $\mathrm{CC} 26 \delta^{13} \mathrm{C}$ values are unusually high for speleothems and can be attributed to the relatively high $\delta^{13} \mathrm{C}$ of the source rock $(-0.1 \%$ to $+2.5 \%$, Laurenzi et al., 1982$)$ and the low contribution from soil $\mathrm{CO}_{2}$ (Dreybrodt, 1982). The latter would be expected from a recharge area characterised by steep terrain, very low soil cover and sparse vegetation. Since the rock value is time-constant, periodic change in soil $\mathrm{CO}_{2}$ production is one of the most likely factors driving $\delta^{13} \mathrm{C}$ variations.

The variability and importance of soil $\mathrm{CO}_{2}$ production in controlling $\delta^{13} \mathrm{C}$ variations in speleothems from the area is further supported by the observation that $\delta^{13} \mathrm{C}$ values of DIC in nearby springs are related to whether or not the recharge altitude is well-vegetated (Doveri et al., 2005). Values as low as $-17 \%$ have been obtained from catchment areas covered by mixed beech and chestnut forest, which contrasts with higher values from the higher elevation, poorly vegetated recharge area above Corchia Cave (Doveri et al., 2005). Speleothems collected from lower-elevation caves reflect this: the $\delta^{13} \mathrm{C}$ values of speleothems from better-vegetated hillslopes range from $-3 \%$ to $-12 \%$ for samples ranging in age from Holocene to $>350 \mathrm{kyr}$ (Zanchetta et al., 2003; Drysdale et al., 2006).

Removing the long-term trend in $\delta^{13} \mathrm{C}$ reveals its shorterterm structure (Fig. 2). Between 5 and $10 \mathrm{kyr}$, the $\delta^{13} \mathrm{C}$ displays a complex pattern of multi-centennial-scale oscillations (Figs. 2 and 3). However, several of these oscillations are superimposed over a relatively broad and prominent interval of decreased $\delta^{13} \mathrm{C}$ starting at ca 8.5 and extending to $7.3 \mathrm{kyr}$, with the most ${ }^{13} \mathrm{C}$-depleted values found between ca 7.9 and $7.4 \mathrm{kyr}$ (Fig. 3). Increases in rainfall and temperature can increase soil $\mathrm{CO}_{2}$ productivity (Raich and Schlesinger, 1992) and reduce speleothem $\delta^{13} \mathrm{C}$ (Genty et al., 2003). Increased rainfall can also limit the opportunity of prior calcite precipitation during seepage (Fairchild et al., 2000), a process that may enrich $\delta^{13} \mathrm{C}$ along the percolation pathway due to progressive degassing of $\mathrm{CO}_{2}$. This latter process would be particularly important at the sample site owing to the $>400 \mathrm{~m}$ travel path taken by the percolation waters in reaching the stalagmite. Moreover, the deep location of the cave chamber and the presence of a well-mixed and stable plumbing system above would inhibit the direct arrival of water not equilibrated with soil $\mathrm{CO}_{2}$ arriving from individual storms, as occurs in shallower caves during "pluvial" periods (e.g. BarMatthews et al., 2000; Frisia et al., 2006). This is also consistent with infrequent measurements of a single active drip point in the chamber over the last $6 \mathrm{yr}$, which show a range of only $3-5$ drips/min.

Thus, the broad period of lower values between ca 8.5 and $7.3 \mathrm{kyr}$ probably reflects an increased input of soil $\mathrm{CO}_{2}$, potentially due to increased rainfall and temperatures, and/or a rainfall-driven decrease in prior calcite precipitation along the flow path. The period of lowest $\delta^{13} \mathrm{C}$ values substantially matches the plateau of lowest $\delta^{18} \mathrm{O}$ values, which possibly indicates the period of maximum amount of rainfall through $\mathrm{S} 1$ in this part of the Mediterranean (ca 7.9-7.4 kyr).

Therefore, the coupled $\delta^{18} \mathrm{O}$ and $\delta^{13} \mathrm{C}$ evidence from CC26 suggests an increase in rainfall at the site. This appears to have reduced sea-surface salinity in the Western Mediterranean Sea, and in turn the isotopic composition of the derived vapour. It is also possible that increased rainfall was coupled to a substantial change in regional circulation promoting the arrival to the site of more rainfall from the North Atlantic, which has a lower isotopic composition compared to Western Mediterranean rainfall.

\section{Discussion and conclusions}

Many terrestrial records over the Mediterranean and North African regions preserve evidence of high rainfall during the Early to Middle Holocene. According to Magny et al. (2002), there was a phase of generally high lake levels at this time. The central Italian crater lakes of Albano and Nemi (Fig. 1) and Lake Pergusa (southern Italy; Fig. 1) also preserves evidence for warmer and wetter conditions during S1 deposition (Ariztegui et al., 2000; Sadori and Narcisi, 2001; Rolph et al., 2004). At Lake Pergusa, the $\delta^{18} \mathrm{O}$ record of authigenic carbonates shows a significant ${ }^{18} \mathrm{O}$-depletion consistent with a substantial increase in rainfall during Early to Middle Holocene in the area (Zanchetta et al., 2006). However, to establish the precise timing of the inferred S1 interval from these sites is difficult due to dating uncertainties (e.g. Oldfield, 1996).

The timing of the shift in $\delta^{18} \mathrm{O}$ from $\mathrm{CC} 26$ record $(8.9 \pm 0.2$ to $7.3 \pm 0.2 \mathrm{kyr})$ is consistent with recent estimates of the duration of $\mathrm{S} 1$ inferred from marine cores taken adjacent to the Italian peninsula (Ariztegui et al., 2000; Marcone et al., 2000; Giunta et al., 2003; Rolph et al., 2004). The timing is also broadly consistent with the speleothem record from Soreq Cave (Israel), where the event is bracketed between 8.5 and $7 \mathrm{kyr}$ (Fig. 4; Bar-Matthews et al., 2000). The small age offset between the two records has to be considered in the context of age uncertainties. During this interval, the Soreq $\delta^{18} \mathrm{O}$ attains 


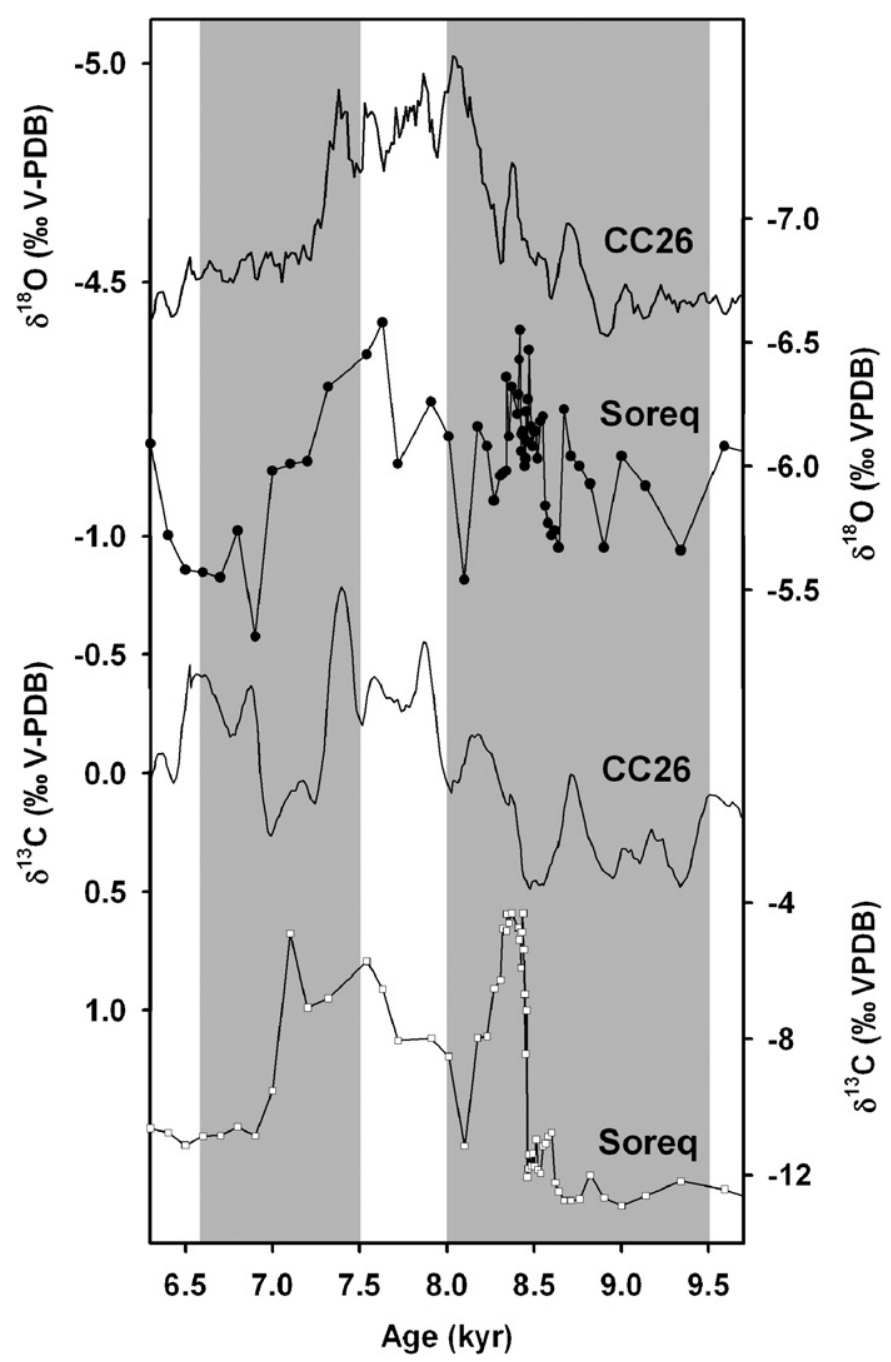

Fig. 4. Comparison between the CC26 isotopic record and the Soreq cave isotopic record during sapropel S1 deposition (the shadowed area as for Fig. 2; the timing of the interruption of $\mathrm{S} 1$ is also shown; data from Ariztegui et al. (2000)). N.B.: The $y$-axes scale for the CC26 $\delta^{18} \mathrm{O}$ and $\delta^{13} \mathrm{C}$ data and for Soreq the $\delta^{18} \mathrm{O}$ data have been inverted.

its lowest Holocene values, consistent with the rainfall amount effect which has been invoked as a major driver of $\delta^{18} \mathrm{O}$ over the last $240 \mathrm{kyr}$ at this site (Bar-Matthews et al., 2000, 2003), whereas the $\delta^{13} \mathrm{C}$ shows an extreme increase of up to $\sim 8 \%$ during $\mathrm{S} 1$, presumably due to a reduction in biogenic $\mathrm{CO}_{2}$ input to the percolation waters caused by either catastrophic soil erosion or a percolation rate so rapid that $\mathrm{CO}_{2}$ equilibration between infiltration water and soil air was not attained (Bar-Matthews et al., 2000). Similarly, Frisia et al. (2006) have speculated that the high $\delta^{13} \mathrm{C}$ values of a speleothem collected at Carburangeli Cave (Sicily, Italy; Fig. 1) was evidence for a period of high rainfall corresponding to the time of $\mathrm{S} 1$ deposition. However, at this site the beginning of this phase cannot be constrained with confidence because the stalagmite started growing at ca $8.5 \mathrm{kyr}$. Since this stalagmite experienced several growth interruptions with no clear climatic significance it cannot be assumed that the onset of its growth was due to "pluvial" conditions.

Many eastern and central Mediterranean marine sites preserve an interruption in S1 deposition, which is usually manifested as a break in organic-rich mud deposition, thought to reflect a brief return to deep-water ventilation (Rohling et al., 1997; De Rijk et al., 1999; Ariztegui et al., 2000; Giunta et al., 2003). The duration and the precise timing of this interruption is debated (e.g. Rohling et al., 1997; Ariztegui et al., 2000; Marcone et al., 2000; Giunta et al., 2003), with estimates varying from ca 500 to $150 \mathrm{yr}$ during the interval ca 8.0-7.5 kyr (Ariztegui et al., 2000). It is equivocal whether such an interruption is preserved in CC26. Closer inspection reveals at least two minor "reversals" in isotopic trends (e.g. at ca 8.3 and $8.6 \mathrm{kyr}$; Fig. 3), but these are of relatively low magnitude. This precludes a direct correlation of the S1 interruption with the CC26 record.

In many records of the Northern Hemisphere there is a prominent climatic deterioration centred at $8.2 \mathrm{kyr}$ (Alley et al., 1997; Alley and Ágústsdóttir, 2005). The lack of prominence of such an event in CC26 is surprising given the apparent widespread extent of this event. Pollen records from Lago di Vico (Magri and Parra, 2002) suggest that in Central Italy at ca $8.1 \mathrm{kyr}$ there is a prominent decrease in arboreal cover indicating drier conditions, which might be consistent with the minor $\delta^{18} \mathrm{O}$ reversal observed in the CC26 record at ca $8.3 \mathrm{kyr}$. However, Emeis et al. (2000) did not find evidence for an increase of surface salinity in the Western Mediterranean Sea at this time, as would be expected from reduced continental runoff, whilst in the eastern part of the basin an increase of sea-surface salinity is evident (Emeis et al., 2000). This indicates that the Western Mediterranean surface water was still depleted in ${ }^{18} \mathrm{O}$, which may have buffered the isotopic signal in the rainfall reaching the cave.

Recently, Rohling and Pälike (2005) have suggested that the anomaly in many records starts from about $8600 \mathrm{yr}$ and forms part of a repeated pattern within the Holocene. The high-resolution $\delta^{18} \mathrm{O}$ time series of CC26 suggests that an event at $8.3 \mathrm{kyr}$ event is proceeded by a similar event at ca $8.6 \mathrm{kyr}$, which is apparent in the Soreq Cave record, in agreement with the observation of Rohling and Pälike (2005). Frisia et al. (2006) also reported occurrence of these events in the Carburangeli Cave and possibly in other speleothems of northern Italy. However, none of these records, including $\mathrm{CC} 26$, contain unequivocal evidence of rapid and prominent climatic deterioration at this time. Any conclusion on the matter is therefore postponed until more high-resolution data from highly sensitive sites are available.

In conclusion, the stable isotope record from CC26 provides the first precisely dated evidence for enhanced rainfall in the Western Mediterranean basin during the time of sapropel $\mathrm{S} 1$ formation. The combined $\delta^{18} \mathrm{O}$ and $\delta^{13} \mathrm{C}$ evidence suggests the phase of highest rainfall 
probably occurred between 7.9 and $7.4 \mathrm{kyr}$, whilst comparison with different marine and lake records, and, in particular, with the Soreq Cave record, indicates substantial in-phase occurrence of enhanced rainfall between Western and Eastern Mediterranean basins.

\section{Acknowledgements}

The authors are indebted to Federazione Speleologica Toscana for the funding of this research, and A. Tait and T. Donnelly for the analytical support for the stable isotope measurements. SUERC is funded by a consortium of Scottish Universities and NERC. RD acknowledges the financial support of the Research Management Committee of the University of Newcastle. We thank M. BarMatthews and S. Frisia for their useful comments, which improved the quality of the paper.

\section{References}

Alley, R.B., Ágústsdóttir, A.M., 2005. The $8 \mathrm{k}$ event: cause and consequences of a major Holocene abrupt climate changes. Quaternary Science Reviews 24, 1123-1149.

Alley, R.B., Mayewsky, P.A., Sowers, T., Stuiver, M., Taylor, K.C., Clark, P.U., 1997. Holocene climatic instability: a prominent, widespread event $8200 \mathrm{yr}$ ago. Geology 25, 483-486.

Ariztegui, D., Asioli, A., Lowe, J.J., Trincardi, F., Vigliotti, L., Tamburini, F., Chondrogianni, C., Accorsi, C.A., Bandini Mazzanti, M., Mercuri, A.M., Van der Kaars, S., McKenzie, J.A., Oldfield, F., 2000. Palaeoclimate and the formation of sapropel S1: inferences from Late Quaternary lacustrine and marine sequences in the central Mediterranean region. Palaeogeography, Palaeoclimatology, Palaeoecology 158, 215-240.

Bard, E., Delaygue, G., Rostek, F., Antonioli, F., Silenzi, S., Schrag, D., 2002. Hydrological conditions in the western Mediterranean basin during the deposition of Sapropel 6 (ca $175 \mathrm{kyr}$ ). Earth and Planetary Science Letters 202, 481-494.

Bar-Matthews, M., Ayalon, A., Kaufmann, A., 2000. Timing and hydrological conditions of sapropel events in the eastern Mediterranean, as evident from speleothems, Soreq Cave, Israel. Chemical Geology 169, 145-156.

Bar-Matthews, M., Ayalon, A., Gilmour, M., Matthews, A., Hawkesworth, C.J., 2003. Sea-land oxygen isotopic relationship from planktonic foraminifera and speleothems in the Eastern Mediterranean region and their implication for paleorainfall during interglacial intervals. Geochimica et Cosmochimica Acta 67, 3181-3199.

Bolle, H.-J., 2003. Climate, climate variability, and impacts in the Western Mediterranean area: an overview. In: Bolle, H.-J. (Ed.), Mediterranean Climate: Variability and Trends. Springer, Berlin, pp. 5-86.

Celle-Jeanton, H., Gonfiantini, R., Travi, Y., Sol, B., 2001. Oxygen-18 variations of rainwater during precipitation: application of the Rayleigh model to select rainfalls in Southern France. Journal of Hydrology 289, 165-177.

Celle-Jeanton, H., Travi, Y., Blavoux, B., 2004. Isotopic typology of the precipitation in the Western Mediterranean region at three different time scales. Geophysical Research Letters 28, 1215-1218.

Dansgaard, W., 1964. Stable isotopes in precipitation. Tellus 4, 436-468.

De Rijk, S., Hayes, A., Rohling, E.J., 1999. Eastern Mediterranean sapropel S1 interruption: an expression of the onset of climatic deterioration around $7 \mathrm{ka}$ BP. Marine Geology 153, 337-343.

Dreybrodt, W., 1982. A possible mechanism for growth of calcite speleothems without participation of biogenic carbon dioxide. Earth and Planetary Science Letters 58, 293-299.
Doveri, M., Leone, G., Mussi, M., Zanchetta, G., 2005. Composizione isotopica di acque ipogee dell'Antro del Corchia (Alpi Apuane, Toscana Nord-Occidentale). Memorie Istituto Italiano Speleologia s 2(18), 119-132.

Drysdale, R.N., Zanchetta, G., Hellstrom, J.C., Fallick, A.E., Zhao, J-x., Isola, I., Bruschi, G., 2004. Palaeoclimatic implications of the growth history and stable isotope $\left(\delta^{18} \mathrm{O}\right.$ and $\left.\delta^{13} \mathrm{C}\right)$ geochemistry of a Middle to Late Pleistocene stalagmite from central-western Italy. Earth and Planetary Science Letters 227, 215-229.

Drysdale, R.N., Zanchetta, G., Hellstrom, J.C., Fallick, A.E., Zhao, J.-x., 2005. Stalagmite evidence for the onset of the Last Interglacial in southern Europe at $129 \pm 1 \mathrm{ka}$. Geophysical Research Letters 32 (L24708).

Drysdale, R., Zanchetta, G., Hellstrom, J., Maas, R., Fallick, A., Cartwright, I., Piccini, L., Pickett, M., 2006. Late Holocene drought responsible for the collapse of Old World civilizations is recorded in an Italian cave flowstone. Geology 34, 101-104.

Drysdale, R.N., Zanchetta, G., Hellstrom, J.C., Fallick, A.E., McDonald, J., Cartwright, I., 2006. Stalagmite evidence for the precise timing of North Atlantic cold events during the early Last Glacial. Geology, in press.

Emeis, K.-C., Struck, U., Schulz, H.-M., Rosenberg, R., Bernasconi, S., Erlekeuser, H., Sakamoto, T., Martinez-Ruiz, F., 2000. Temperature and salinity variations of Mediterranean Sea surface waters over the last 16,000 years from records of planktonic stable oxygen isotopes and alkenone unsaturation ratios. Palaeogeography, Palaeoclimatology, Palaeoecology 158, 259-280.

Fairchild, I.J., Borsato, A., Tooth, A.F., Frisia, S., Hawkesworth, C.J., Huang, Y., McDermott, F., Spiro, B., 2000. Controls on trace element $(\mathrm{Sr}-\mathrm{Mg})$ composition of carbonate cave waters: implications for speleothem climatic records. Chemical Geology 166, 255-269.

Frisia, S., Borsato, A., Fairchild, I., McDermott, F., 2000. Calcite fabrics, growth mechanisms, and environments of formation in speleothems from the Italian Alps and southwestern Ireland. Journal of Sedimentary Petrology 70, 1183-1196.

Frisia, S., Borsato, A., Mangini, A., Spötl, C., Madonna, G., 2006. Holocene climate varibility from a discontinuous stalagmite record and the Mesolithic to Neolithic transition. Quaternary Research 66, 388-400.

Gagan, M.K., Chivas, A.R., Isdale, P.J., 1994. High-resolution isotopic records from corals using ocean temperature and mass-spawning chronometers. Earth and Planetary Science Letters 121, 549-558.

Gascoyne, M., 1992. Palaeoclimate determination from cave calcite deposits. Quaternary Science Reviews 11, 609-632.

Genty, D., Blamart, D., Ouahdi, R., Gilmour, M., Baker, A., Jouzel, J., Van-Exter, S., 2003. Precise dating of Dansgaard-Oeschger climate oscillations in the western Europe from stalagmite data. Nature 421, 833-837.

Giunta, S., Negri, A., Morigi, C., Capotondi, L., Combourieu-Nebout, N., Emeis, K.C., Sangiorgi, F., Vigliotti, L., 2003. Coccolithophorid ecostratigraphy and multi-proxy paleoceanographic reconstruction in the Southern Adriatic Sea during the last deglaciation time (Core AD91-17). Palaeogeography, Palaeoclimatology, Palaeoecology 190, $39-59$.

Hellstrom, J.C., 2003. Rapid and accurate U/Th dating using parallel ioncounting multi-collector ICP-MS. Journal of Analytical Atomic Spectrometry 18, 135-136.

Hurrell, J.W., Kushnir, Y., Ottersen, G., Visbeck, M., 2003. An overview of the North Atlantic Oscillation. In: Hurrell, J.W., Kushnir, Y., Ottersen, G., Visbeck, M. (Eds.), The North Atlantic Oscillation: Climatic Significance and Environmental Impact. Geophysical Monograph, vol. 134. AGU, Washington, DC, pp. 1-35.

Kallel, N., Paterne, M., Labeyrie, L., Duplessy, J.-C., Arnold, M., 1997. Temperature and salinity records of the Tyrrhenian Sea during the last 18,000 years. Palaeogeography, Palaeoclimatology, Palaeoecology 135, $97-108$.

Kallel, N., Duplessy, J.-C., Labeyrie, L., Fontugne, M., Paterne, M., Montacer, M., 2000. Mediterranean pluvial periods and sapropel 
formation over the last 200000 years. Palaeogeography, Palaeoclimatology, Palaeoecology 157, 45-58.

Kim, S.-T., O'Neil, J.R., 1997. Equilibrium and non-equilibrium oxygen isotope effect in synthetic carbonates. Geochimica et Cosmochimica Acta 61, 3461-3475.

Krom, M.D., Stanley, J.D., Cliff, R.A., Woodward, J.C., 2002. Nile River sediment fluctuation over the past $7000 \mathrm{yr}$ and their role in sapropel development. Geology 30, 71-74.

Laurenzi, M.A., Tucci, P., Turi, B., 1982. Considerazioni geotermometriche sulle formazioni metamorfiche di età meso-cenozoiche del settore del M. Corchia. Periodico Mineralogia 52, 189-204.

Magny, M., Miramont, C., Sivan, O., 2002. Assessment of the impact of climate and anthropogenic factors on Holocene Mediterranean vegetation in Europe on the basis of palaeohydrological records. Palaeogeography, Palaeoclimatology, Palaeoecology 186, 47-59.

Magri, D., Parra, I., 2002. Late Quaternary western Mediterranean pollen records and African winds. Earth and Planetary Science Letters 200, 401-408.

Marcone, D., Thomson, J., Croudace, I.W., Siani, G., Paterne, M., Troelstra, S., 2000. Duration of S1, the most recent Eastern Mediterranean sapropel, as indicated by AMS radiocarbon and geochemical evidence. Paleoceanography 15, 336-347.

Mayewski, P.A., Rohling, E.E., Stager, J.C., Karlén, W., Maasch, K.A., Meeker, L.D., Meyerson, E.A., Gasse, F., van Kreveld, S., Holmgren, K., Lee-Thorp, J., Rosqvist, G., Rack, F., Staubwasser, M., Schneider, R.R., Steig, E.J., 2004. Holocene climate variability. Quaternary Research 62, 243-255.

Oldfield, F., 1996. The PALICLAS Project: synthesis and overview. In: Oldfield, F., Gulizzoni, P. (Eds.), Palaeoenvironmental analysis of Italian crater Lake and Adriatic sediments. Memorie Istituto Italiano Idrobiologia, vol. 55. pp. 329-357.

Pierre, C., 1999. The oxygen and carbon isotope distribution in the Mediterranean water masses. Marine Geology 153, 41-55.

Raich, J.W., Schlesinger, W.H., 1992. The global carbon dioxide flux in soil respiration and its relationship with vegetation and climate. Tellus 44B, 81-99.

Rohling, E.J., 1994. Review and new aspects concerning the formation of eastern Mediterranean sapropels. Marine Geology 122, 1-28.
Rohling, E.J., Pälike, H., 2005. Centennial-scale climate cooling with a sudden cold event around 8,200 years ago. Nature 434, 975-979.

Rohling, E.J., Jorissen, F.J., De Stigter, H.C., 1997. $200 \mathrm{yr}$ interruption of Holocene sapropel formation in the Adriatic Sea. Journal of Micropalaoentology 16, 97-108.

Rolph, T.C., Vigliotti, L., Oldfield, F., 2004. Mineral magnetism and geomagnetic secular variation of marine and lacustrine sediments from Central Italy: timing and nature of local and regional Holocene environmental change. Quaternary Science Reviews 23, 1699-1722.

Rossignol-Strick, M., 1999. The Holocene climatic optimum and pollen records of sapropel in the eastern Mediterranean, 9000-6000 BP. Quaternary Science Reviews 18, 515-530.

Rossignol-Strick, M., Nesteroff, W., Olive, P., Vergnaud-Grazzini, C., 1982. After the deluge: Mediterranean stagnation and sapropel formation. Nature 295, 105-110.

Sadori, L., Narcisi, B., 2001. The postglacial record of environmental history from Lago di Pergusa. The Holocene 11, 655-670.

Siani, G., Paterne, M., Michel, E., Sulpizio, R., Sbrana, A., Arnold, M., Haddad, G., 2001. Mediterranean Sea surface radiocarbon reservoir age changes since the Last Glacial Maximum. Science 294, 1917-1920.

Sperling, M., Schmiedl, G., Hemleben, Ch., Emeis, K.C., Erlekeuser, H., Grootes, P.M., 2003. Black Sea impact on the formation of eastern Mediterranean S1? Evidence from Marmara Sea. Palaeogeography, Palaeoclimatology, Palaeoecology 190, 9-21.

Thomson, J., Mercone, D., de Lange, G.J., van Satvoort, P.J.M., 1999. Review of recent advances in the interpretation of eastern Mediterranean sapropel S1 from geochemical evidence. Marine Geology 153, 77-89.

Zanchetta, G., Drysdale, R.N., Hellstrom, J.C., Fallick, A.E., Zhao, J.X., Bonadonna, F.P., Isola, I., Bruschi, G., 2003. The $\delta^{13} \mathrm{C}$ in stalagmites from the Alpi Apuane karst (Central Italy) as a proxy for the morphological and tectonic evolution of the area. GEOITALIA 2003, IV Forum Italiano di Scienze della Terra, Bellaria 16-18 Settembre 2003, Abstract vol. pp. 465-466.

Zanchetta, G., Borghini, A., Fallick, A.E., Bonadonna, F.P., Leone, G., 2006. Late Quaternary palaeohydrology of Lake Pergusa (Sicily, southern Italy) as inferred by stable isotopes of lacustrine carbonates. Journal of Paleolimnology, in press, doi:10.1007/s10933-006-9070-1. 